\title{
An Experimental Study on the Influence of Milk Aspiration on Bronchial Reactivity to Cigarette Smoke in Guinea Pigs
}

\author{
Shigeyuki Yamada and Nobuo Sakurai \\ Department of Hygiene, Hamamatsu University School of Medicine, Hamamatsu
}

\section{INTRODUCTION}

It has been reported that bottle-fed infants developed bronchial asthma and bronchitis more often than breast-fed ones ${ }^{1 \sim 31}$ and that the prognosis for asthma in the former was poorer than in the latter ${ }^{4}$. It was also shown that a history of childhood respiratory trouble was associated with a greatly increased risk of various respiratory symptoms among adults ${ }^{5 \sim 7)}$. Therefore, it appears that long-term alteration or modification of the constitution may occur among people who experienced bottle feeding at an early age.

In addition, several studies have noted that the incidence of sudden unexpected death was higher in bottle-fed infants than in the breast-fed ones ${ }^{8,9)}$, and Barrett ${ }^{101}$ claimed that this syndrome was due to the inhalation of cow's milk into the respiratory tract. In other words, alteration of the reactivity of the airways may be caused by the aspiration of milk formulae, a condition which is observed habitually during bottle-feeding, and may be subsequently aggravated with irritating substances produced in the living environment such as cigarette smoke.

This report presents the experimentally altered reactivity of respiratory tracts to cigarette smoke among guinea pigs inoculated intratracheally with cow's milk in infancy.

\section{MATERIALS AND METHODS}

Preparation of animals for experiments. Twenty-five $\mu 1$ of $10 \%$ skim milk solution was inoculated into the trachea of two-week-old male guinea pigs of the Hartlay strain under aseptic conditions. After stitching the incision, the animals were kept in conventional conditions for three weeks. After wards the skim milk solution was inoculated into the trachea again. They were designated the milk-inoculated group. As a control, physiological saline was introduced into a saline-inoculated group in the same manner as the milk-inoculated group. One week after the second inoculation the animals were subjected to smoking.

\section{Smoking.}

Mainstream smoke exposure: For the examination of respiratory sounds, respiratory rates and serum and lung histamine levels, eleven animals of the milk-inoculated group and nine from the saline-inoculated one received mainstream smoke exposure. The animals were exposed to mainstream smoke in a Hamburg II inhalation apparatus (Heinr. Borgwaldt, Hamburg, West Germany) as developed by Dontenwill ${ }^{11}$ and designed to deliver a fresh mixture of smoke and air at a ratio of $1: 7$. The animals were exposed to one round of thirty cigarettes in approximately 8 minutes. The exposure was repeated for two rounds every second day for five months.

Sidestream smoke exposure: Sidestream smoke is alkalescent because the ammonia content is higher than that of mainstream smoke. The irritability induced by nicotine is heightened in an alkalescent atmosphere, so that it brings on complicated changes of the functions of the respiratory and cardiovascular systems through the nasopharyngeal reflex $^{12)}$. Therefore, for the examination of beat-to-beat heart rate variability, sixteen animals in each group were subjected to sidestream smoke exposure in the following way: A desicator with a fifteen-liter capacity was partitioned into two areas by a bored plate. 
Four animals were put in the upper area on the plate and three lighted cigarettes were placed under that. Then it was covered and 4.3 liters of fresh air per minute were blown into it by a diaphragm pump. The animals were kept inside for twelve minutes and the cover was opened to replace the cigarettes, after which they were kept inside for twelve minutes more. The procedure was performed once every second day for four months.

Sonogram. The respiratory sounds were recorded by means of a small tape recorder (Sony, TC-150, Tokyo) immediately after the last exposure to mainstream smoke at the fifth month. The sounds were analyzed by means of a sound spectrographic analyser (Rion Co. Ltd., SG-07, Tokyo). It was not possible to record respiratory sounds before the exposure.

Respirogram. The respirogram was recorded by a body-plethysmograph(Fig. 1) before the last exposure to mainstream smoke at the fifth month and immediately after the recording of respiratory sounds. The respiratory rate was obtained by counting the number of peaks per time unit in a respirogram.

Electrocardiogram. Before the exposure to sidestream smoke, the animals in both groups were examined by electrocardiography once a month as follows: Their limbs were placed on a copper-plate, which was $5 \times 10 \mathrm{~cm}$ wide, and connected to a portable electrocardiograph (Nihonkoden Co. Ltd., MC-12, Tokyo). The animals usually did not show any excitement during the examination. Seventy consecutive $\mathrm{R}-\mathrm{R}$ intervals in an electrocardiogram strip were measured with calipers down to two places of decimals in the millimeter unit. The coefficient of beat-to-beat variation $(\mathrm{CV})$ was calculated with the following formula : $\mathrm{CV}=(\mathrm{SD} / \overline{\mathrm{X}}) \times 100$.

Measurement of histaminase activity in blood plasma. Before the last exposure to mainstream smoke, that is, immediately after the first respirogram recording, one $\mathrm{m} l$ of blood was obtained from the external jugular vein by a disposable syringe with heparin. The blood plasma was separated by centrifugation. The histaminase activity in the plasma was measured by the o-dianisidine-peroxidase method ${ }^{13)}$.

Measurement of histamine content in the lung. After the last exposure to mainstream smoke, that is, immediately after the second respirogram recording, the animals were sacrificed by exsanguination. The right lower pulmonary lobe was removed and stored in a freezer at $-40^{\circ} \mathrm{C}$. Before examination, the frozen lobe was washed quickly with physiological saline and wiped with filter paper. After measurement of the weight, it was homogenized in a glass homogenizer with $0.4 \mathrm{~N}$ perchloric acid at a rate of $25 \mathrm{~m} l$ per gram by cooling in an ice bath. The homogenate was centrifuged at $12,000 \mathrm{rpm}$ for 20 minutes at $0^{\circ} \mathrm{C}$. Histamine in the supernatant was determined by the fluorometric method ${ }^{14}$.

\section{RESULTS}

Sonogram and respirogram. The animals showed dyspnea after approximately three months exposure to the mainstream smoke.

The respirogram of an animal attacked with severe dyspnea showed slow respiration (Fig. 2A). Its sonogram revealed wheezing during the paroxysm of dyspnea (Fig. 3A) and displayed two kinds of frequency component. The higher one was above $6,000 \mathrm{~Hz}$ and the lower one under $4,500 \mathrm{~Hz}$. The

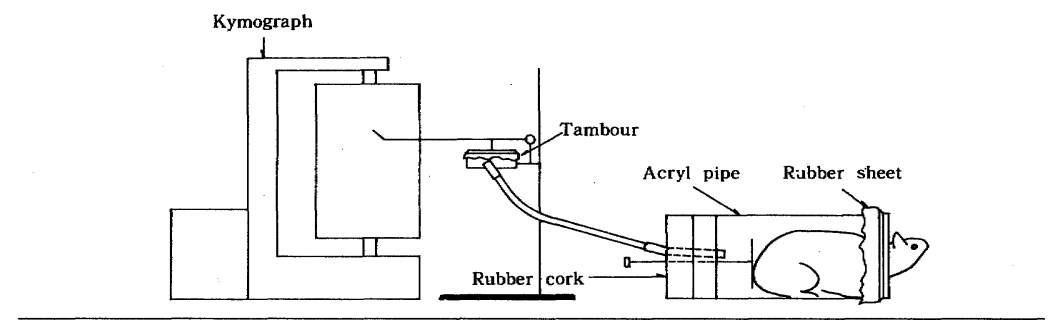

Fig. 1 Diagram of body-plethysmograph. 
A After Exposure

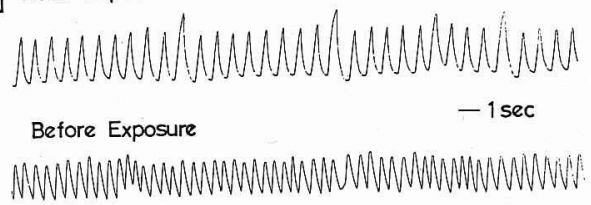

B After Exposure

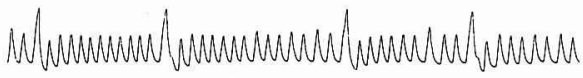

Before Exposure

$-1 \mathrm{sec}$

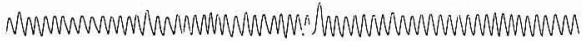

C

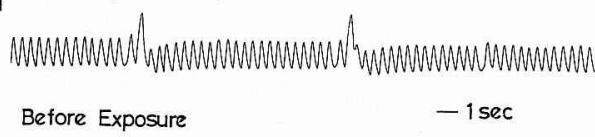

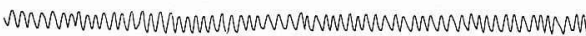

Fig. 2 Respirograms before and after exposure to mainstream smoke. A : milk-inoculated group No. 2; B : milk-inoculated group No.10; C: salineinoculated group No. 9.
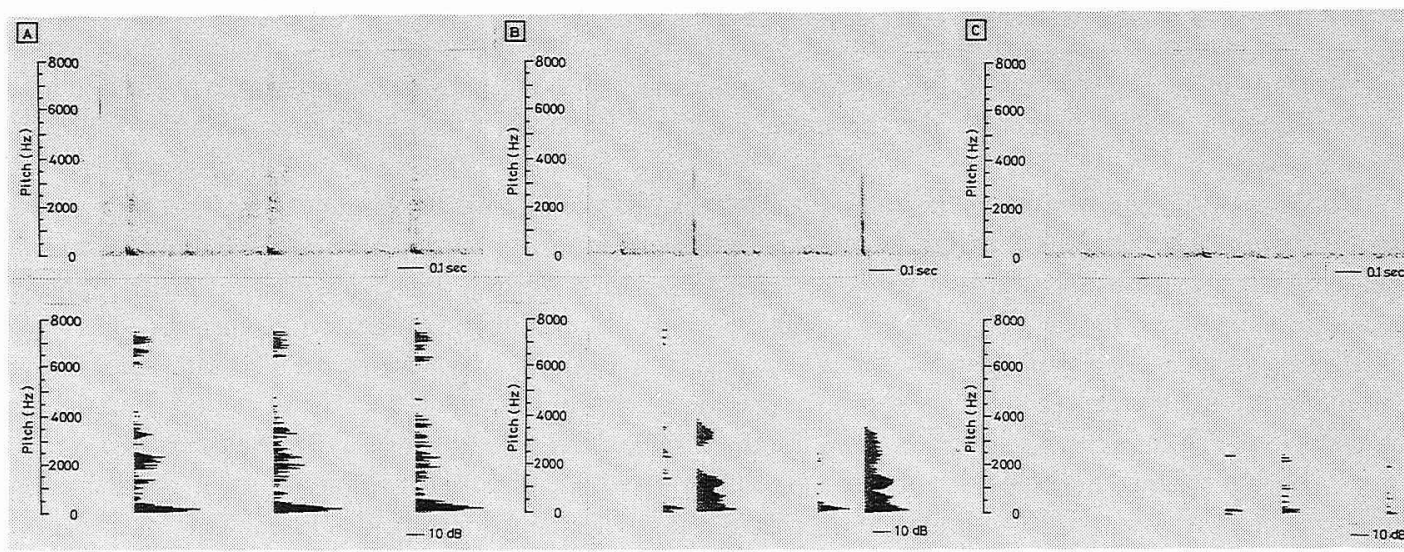

Fig. 3 Sonograms after exposure to mainstream smoke. A: milk-inoculated group No. 2; B: milkinoculated group No. 10 ; C: saline-inoculated group No. 9. The upper pictures show the auditory phases that become visible when respiratory sounds are recorded. The lower pictures show the pitch of sounds at the appropriate time in the upper pictures. The vertical and horizontal axes represent the levels of the sound components and their pitches, respectively.

Table 1 Respiratory rate before and after exposure to mainstream smoke ${ }^{\#}$.

\begin{tabular}{lccc}
\hline & $\begin{array}{c}\text { Before exposure } \\
\text { (beats/min) }\end{array}$ & $\begin{array}{c}\text { After exposure } \\
\text { (beats/min) }\end{array}$ & $\begin{array}{c}\text { After/Before } \\
\text { (\%) }\end{array}$ \\
\hline Milk-inoculated group (11) & $119.2 \pm 3.8$ & $86.5 \pm 5.9^{*}$ & $72.2 \pm 3.7$ \\
Saline-inoculated group (9) & $120.5 \pm 5.9$ & $102.3 \pm 8.8$ & $85.2 \pm 6.1$ \\
\hline
\end{tabular}

${ }^{*}:$ Values are expressed as mean \pm sem. Figures in parentheses indicate the number of animals. ${ }^{*}:$ Statistically significant difference from before exposure with $p<0.01$ using $\mathrm{t}$ test.

respirogram of an animal showing a slight dyspnea revealed moderately slow respiration (Fig. 2B). The high frequency components were hardly seen in its sonogram (Fig. 3B). The respirogram of an animal without dyspnea did not show any slow respiration (Fig. 2C) and hardly any respiratory sounds were recorded (Fig. 3C).

Sound characteristics higher than $6,000 \mathrm{~Hz}$ and larger than $5 \mathrm{~dB}$ were observed in $63.6 \%$ (seven of 
Table 2 Histaminase activity in blood plasma and histamine content in the lungs after five months' exposure to mainstream smoke".

\begin{tabular}{lcc}
\hline & $\begin{array}{c}\text { Histaminase activity } \\
(\mathrm{m} \mu \mathrm{mol} / \mathrm{m} l / \mathrm{min})\end{array}$ & $\begin{array}{c}\text { Histamine content } \\
(\mu \mathrm{g} / \mathrm{g} \text { wet tissue })\end{array}$ \\
\hline Milk-inoculated group (11) & $4.750 \pm 0.633^{*}$ & $12.0 \pm 1.0$ \\
Saline-inoculated group (9) & $2.811 \pm 0.507$ & $14.4 \pm 1.7$ \\
\hline
\end{tabular}

\# : Values are expressed as mean \pm sem. Figures in parentheses indicate the number of animals. * : Statistically significant difference from saline-inoculated group with $p<0.05$ using $\mathrm{t}$ test.

eleven cases) in the milk-inoculated group and in 33.3\% (three of nine cases) in the saline-inoculated one.

The decrease of respiratory rate after exposure to the mainstream smoke was more marked in the milk-inoculated group than in the salin-inoculated one. The ratio of the respiratory rate after exposure to that before exposure was smaller in the former group (Table 1).

Histaminase activity in blood plasma and histamine content in the lung. Although the histaminase activity in the plasma of the milk-inoculated group was 1.7 times greater than that of the saline-inoculated one, the histamine content in the lung was lower in the former group (Table. 2).

Coefficient of beat-to-beat variation in electrocardiogram. There was a diminution in the coefficients of beat-to-beat variation as time elapsed in both groups, but the coefficients in the milk-inoculated group were usually larger than those in the saline-inoculated one (Fig. 4).

\section{DISCUSSION}

Mimicking the aspiration of milk in bottle-fed infants, Tanamura ${ }^{15)}$ carried out only one inoculation

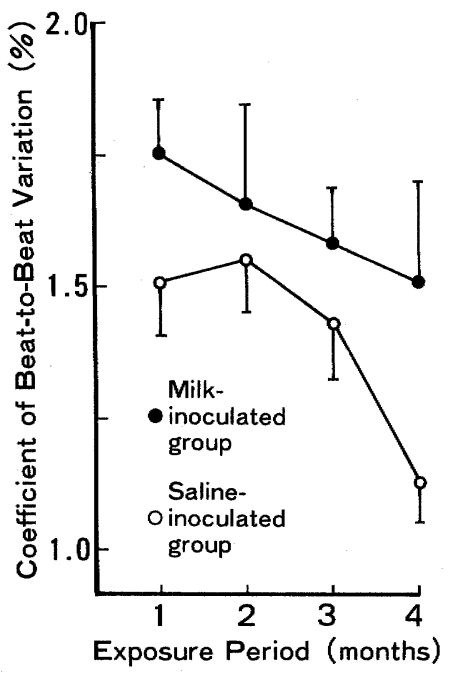

Fig. 4 Change of coefficient of beat-to-beat variation during the period of sidestream smoke exposure. Date are expressed as mean \pm sem (16 cases).

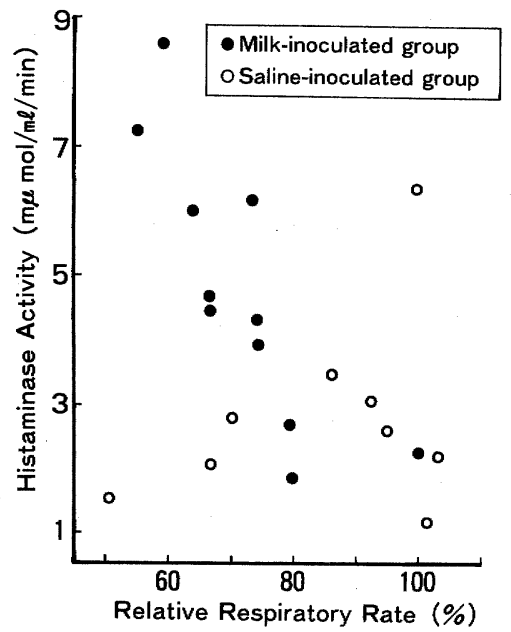

Fig. 5 Relationship between histaminase activity in blood plasma and relative respiratory rate before and after exposure to mainstream smoke. The rank-correlation coefficient is -0.93 in the milkinoculated group and 0.08 in the saline-inoculated one. The relationship in the former is statistically significant with $p<0.01$. 
of a small amount of cow's milk into the trachea of new-born and two-week-old guinea pigs. One and a half months after the inoculation, he confirmed antibodies to cow's milk proteins in their sera and demonstrated anaphylactic reactions induced by intratracheal administration of cow's milk. The authors ${ }^{16,17)}$ gave a similar inoculation of cow's milk to two-week-old guinea pigs and, one year after the inoculation, demonstrated asthmatoid wheeze induced by intratracheal instillation of extracts obtained from the feces of cockroaches and sea bottom sediments from Tokyo Bay. These results appeared to suggest that the aspiration of milk in infancy brought about alteration of the reactivity of airways and made them hypersensitive to various environmental factors.

Exposed to cigarette smoke for a long period, the guinea pigs inoculated intratracheally with cow' $s$ milk showed dyspnea after the exposure. The respiratory sounds accompanied by severe dyspnea contained high-pitched components (Fig. 3A). These components were rarely seen in slight dyspnea. Thus, the high-pitched components appeared to show the presence of severe dyspnea. The sound spectrographic analyses of respiratory sounds after smoking revealed that components higher than 6,000 $\mathrm{Hz}$ were more common in the milk-inoculated group than in the saline-inoculated one.

The increased resistance to air passage due to bronchoconstriction produces a slowdown of respiration, the degree of which corresponds in general to the intensity of dyspnea. Therefore, the ratio of the respiratory rate after exposure to that before exposure represents the degree of the intensity of dyspnea ; that is, the smaller the value of the ratio, the more severe the dyspnea. It is actually smaller in the milk-inoculated group than in the saline-inoculated one (Table 1). In other words, the intensity of dyspnea in the former is higher than in the latter.

Saindelle et al. ${ }^{18)}$ reported that formaldehyde, acrolein, and acetaldehyde, which were contained in cigarette smoke, released histamine from the lungs of guinea pigs and induced bronchial constriction. Krajewska et al. ${ }^{19)}$ found that plasma histaminase activity was elevated for a period of twelve days by the inhalation of $1 \%$ histamine solution for 1 to 5.25 minutes. Therefore, the lower histamine content in the lung of the milk-inoculated group seems to indicate the release of histamine from the lung tissue by smoke stimuli and it appears that the released histamine elevates the histaminase activity as shown in Table 2 and constricts the smooth muscle of the respiratory tree to bring on severe dyspnea.

Since the intensity of dyspnea is represented as the decrease in the ratio of the respiratory rate after exposure to that before exposure, there may be a negative correlation between the histaminase activity and the ratio of the respiratory rate. Actually, a statistically significant negative correlation is observed in the milk-inoculated group, not in the saline-inoculated one (Fig. 5). These results appear to show the release of histamine in the lungs of the milk-inoculated group too.

As the bronchial constriction caused by histamine is reduced by vagal cooling, vagotomy, or the administration of atropine ${ }^{20,21)}$, it is believed that the vagus nerves regulate the bronchial constriction and that high vagal tone provides the basis of bronchial hypersensitivity and intensifies the constriction of the respiratory tree. The vagal tone is represented by the coefficient of the beat-to-beat variation. When the vagal tone increases, the coefficient becomes larger ${ }^{22,23)}$. The results shown in Fig. 4 may indicate that the vagal tone in the milk-inoculated group is higher than in the saline-inoculated one. The severe dyspnea in the former, therefore, would be due to the high vagal tone and further the release of histamine in the lungs.

Blair ${ }^{4}$ examined the severity and persistence of childhood asthma as a function of infant-feeding practices with a twenty-year follow-up. Asthmatic children were placed into three groups according to their mode of infant-feeding : breast feeding for eight weeks or more, up to one week, and none. Definite improvement of the prognosis was shown in the first group both in five- and twenty-year follow-up analyses. It was seen in the second group only in the five-year follow-up. There was no improvement in the third group at any stage. Although he does not draw any conclusion about the reason for these differences, on the basis of this report it may be claimed that the aspiration of cow's milk in infancy may be one of the essential causes of the differences described above. 


\section{SAMMARY}

Guinea pigs inoculated intratracheally with cow's milk in infancy (milk-inoculated group), which were designed as a model of the aspiration of milk formulae in bottle-fed infants, were exposed to cigarette smoke to investigate their respiratory response. Guinea pigs received physiological saline instead of cow's milk were also exposed to the smoke as a control (saline-inoculated group). After exposure for a period of five months, dyspnea was observed immediately after smoking, with an incidence of $63.6 \%$ in the milk-inoculated group and $33.3 \%$ in the saline-inoculated one. The ratio of the respiratory rate after exposure to that before exposure was $72.7 \%$ in the former group and $85.2 \%$ in the latter group, which suggested that the intensity of dyspnea in the milk-inoculated group was higher than in the saline-inoculated one. Although histaminase activity in blood plasma of the former group was 1.7 times greater than that of the latter, histamine content in the lung was lower in the former. The coefficient of beat-to-beat variation was larger in the former. It was revealed from these results that high vagal tone and the histamine release from the lung induced by smoking were present in the milk-inoculated group. Consequently, the aspiration of cow's milk in infancy appears to be able to alter the reactivity of the airways, making them hypersensitive to cigarette smoke.

Acknowledgment: This reseach was supported in part by a grant from the Steel Industry Foundation for Advancement of Protection Technology, Contract No. 54-34.

\section{REFERENCES}

1) Hide, D.W. and Guyer, B.M. : Clinical manifestations of allergy related to breast and cow's milk feeding, Arch. Dis. Child., 56, 172-175 (1981).

2) Kaufman, H.S. and Frick, O.L. : Prevention of asthma, Clin. Allergy, 11, 549-553 (1981).

3) Fregusson, D.M., Horwood, L.J. and Shannon, F.T. : Asthma and infant diet, Arch. Dis Child., 58, 48-51 (1983).

4) Blair, H. : Natural history of childhood asthma. 20-year follow-up, Arch. Dis. Child., 52, 613-619 (1977).

5) Burrows, B., Knudson, R.J. and Lebowitz, M.D.: The relationship of childhood respiratory illness to adult obstructive airway disease, Am. Rev. Respir. Dis., 115, 751-760 (1977).

6) Colley, J.R.T., Douglas, J.W.B. and Reid, D.D. : Respiratory disease in young adults : Influence of early childhood lower respiratory tract illness, social class, airpollution, and smoking, Brit. Med. J., 3, 195-198 (1973).

7) Oswald, N.C., Harold, J.T. and Martin, W.J. : Clinical pattern of chronic bronchitis, Lancet, 2, 639-643 (1953).

8) Ministry of Health : Enquiry into sudden death in infancy. Reports on Public Health and Medical Subjects No. 113, Her Majesty's Stationary Office, London (1965).

9) Carpenter, R.G. and Shaddick, C.W.: Role of infection, suffocation, and bottle-feeding in cot death. An analysis of some factors in the histories of 110 cases and their controls, Brit. J. Prev. Soc. Med., 19, 1-7 (1965).

10) Barrett, A.M. : Sudden death in infancy. In: Gairdner, D. (ed) Recent Advances in Paediatrics, 1st Edn, p. 301 -320 , Churchill, London (1954).

11) Dontenwill, W. : Experimental investigations on the effect of cigarette smoke inhalation on small laboratory animals. In: Hanna, M.G., Nettesheime, J. and Gilbert, J.R.(eds) Inhalation Carcinogenesis, p. 389-412, Washington, D.C., U.S. Atomic Energy Commission (1970).

12) Schmidt, F.: Tabakrauch als wichtigste Luftverschmutzung in Innenraumen und als pathogene Noxe fur Passivraucher, Med. Welt, 25, 1824-1832 (1974).

13) Gordon, G.R. and Peters, J.H.: Plasma histaminase activity in various mammalian species; A rapid method of assay, Proc. Soc. Exp. Biol. Med., 124, 399-404 (1967).

14) Redlich, D. and Glick, D.: Studies in histochemistry. LXXVI. Fluorometric determination of histamine in microgram sample of tissue or microliter of body fluids, Anal. Biochem., 10, 459-467 (1965).

15) Tanamura, H.: Fundamental studies on mechanisms of milk-allergy - especially on mechanisms of sudden death in infancy (in Japanese), Chiba Med. J., 49, 33-41 (1973).

16) Sakurai, N., Matsushima, H., Yamada, S., Ichinose, N., Kawakami, H., Miyano, K., Tada, K., Saito, H. and Umeda, M. : Induction of experimental asthma in milk-immunized guinea pigs with organics extracted from dry sea bottom sediments by organic solvent (in Japanese), Medicine and Biology, 94, 291-296 (1977).

17) Sakurai, N., Yamada, S., Matsushima, H., Ichinose, N., Kawakami, H., Miyano, K., Tada, K., Saito, H. and Umeda, M. : Experimental respiratory disorder in guinea pigs caused with organics extracted from sea 
bottom sediments - especially on the band-analysis of squeaking (in Japanese), Medicine and Biology, 98, 181-186 (1979).

18) Saindelle, A., Flavian, N., Guillerm, R. and Hée, J.: Libération d'histamine par la fumée de cigarette et ses constituants, C.R. Hebd. Séanc. Acad. Sci. D. : Sci. Nat., 264, 2926-2968 (1967).

19) Krajewska, J.M. and Maslinski, C. : Plasma diamine oxidase activity after single or chronic administrations of histamine, Europ. J. Pharmacol., 7, 300-306 (1967).

20) Karczewski, W. and Widdicombe, J.G.: The role of the vagus nerves in the respiratory and circulatory responses to intravenous histamine and phenyl diguanide in rabbits, J. Physiol., 201, 271-291 (1969).

21) Simonsson, B.G., Jacobs, F.M. and Nadel, J.A.: Role of autonomic nervous system and the cough reflex in the increased responsiveness of airways in patients with obstructive airway disease, J. Clin. Invest., 46, 1812-1818 (1967).

22) Wheeler, T. and Watkins, P.J. : Cardiac denervation in diabetes, Br. Med. J., 4, 584-586 (1973).

23) Ewing, D.J. : Cardiovascular reflexes and autonomic neuropathy, Clin. Sci. Mol. Med., 55, 321-327 (1978).

\title{
シガレット煙に対するモルモットの気道反応性の 経気管的ミルク注入による影響
}

\author{
浜松医科大学衛生学教室 \\ 山田 重 行・櫻 井信 夫
}

人工栄養児のミルク誤噮を模して, 幼弱期に微量のミルクを気管内注入したモルモット（ミルク注入群）と生理食塩 水を注入した対照群とに喫煙を負荷し，シガレット煙に対する呼吸器系の反応性について比較検討した。

5 ヶ月間のシガレット煙曝露の後, 吸煙直後に観察された呼吸困難の発生率はミルク注入群で $63.6 \%$, 対照群で 33.3

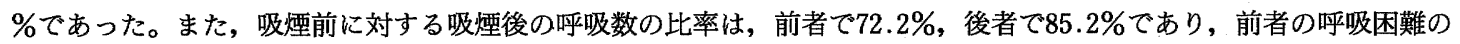
強いことが示された。血漿ヒスタミナーゼ活性は, 前者の方が高くて後者の1.7倍であったが, 肺ヒスタミン含量は前者 の方が低かった。心電図 RR 間隔の変動係数は前者が高かった。

以上の結果から, ミルク注入群には迷走神経の緊張と吸煙刺激による肺からのヒスタミン遊離があり, 幼弱期におけ るミルク誤嚥により気道の反応性が変更されシガレット煙に対する過敏性のもたらされることが示唆された。

Key words : Cigarette smoking, Milk aspiration, Bronchial reactivity, Histamine release, $R R$ interval variation 喫煙，ミルク誤睘，気道反応性，ヒスタミン遊離， RR 間隔変動 